\title{
Food and feeding ecology of the swordfish Xiphias gladius in the western North Atlantic Ocean with estimates of daily ration*
}

\author{
C. E. Stillwell \& N. E. Kohler \\ National Oceanic and Atmospheric Administration, National Marine Fisheries Service, Northeast Fisheries Center, \\ Narragansett Laboratory, South Ferry Road, Narragansett, Rhode Island 02882, USA
}

\begin{abstract}
Analysis of stomach contents and predator-prey relations of 168 swordfish from the western North Atlantic Ocean is presented. The predominant food of swordfish is squid $(82 \%$ by frequency of occurrence) followed by fish (53\%) consisting primarily of gadids, scombrids, butterfish, bluefish, and sand lance. Average food volume in stomachs is $1 \%$ of average body weight. Estimates of daily ration range from $0.94 \%$ to $1.6 \%$ of average body weight, with yearly consumption ranging from 3.4 to 5.8 times average body weight per year. The prey biomass consumed by the swordfish population in the Georges Bank area is estimated to range from 2,100 to 11,000 mt over a residency time of 5 mo.
\end{abstract}

\section{INTRODUCTION}

The swordfish Xiphias gladius is a large predatory marine fish distributed worldwide between Latitudes $45^{\circ} \mathrm{N}$ to $45^{\circ} \mathrm{S}$ (Sakagawa \& Bell 1980). In the western Atlantic Ocean, swordfish range from the coast of Newfoundland to Argentina (Tibbo et al. 1961, de Sylva 1962, Wise \& Davis 1973). The food of swordfish throughout their range has been described by numerous authors (Bigelow \& Schroeder 1953, Tibbo et al. 1961, Scott \& Tibbo 1968, 1974, Beckett 1974, Palko et al. 1981). Scott \& Tibbo (1968) were the first to provide quantitative measurements of the food items found in swordfish stomachs. Despite the many observations by the above authors on the food of swordfish, no attempts have been made to estimate the daily ration or biomass of prey consumed by this species. The purpose of this research was to expand the understanding of the feeding ecology of the swordfish in the western North Atlantic with respect to diet, feeding behavior, and food consumption. This paper is a contribution to the MARMAP program of the National Marine Fisheries Service.

\section{METHODS}

Stomach samples were collected from swordfish captured by commercial and research vessels using long-

\footnotetext{
- MARMAP Contribution MED/NEFC 82-69
}

lines from 1975-81 and from a sport fishing tournament held in Ocean City, New Jersey during August 1979 and 1980. All stomachs were from fish caught along the slope and margin of the continental shelf between Cape Hatteras, N. C. (USA) and the Tail of the Grand Banks (Fig. 1). Stomachs were examined from fish collected during all months except January, with the majority (116) being taken from May through October.

The contents of most stomachs were examined at sea

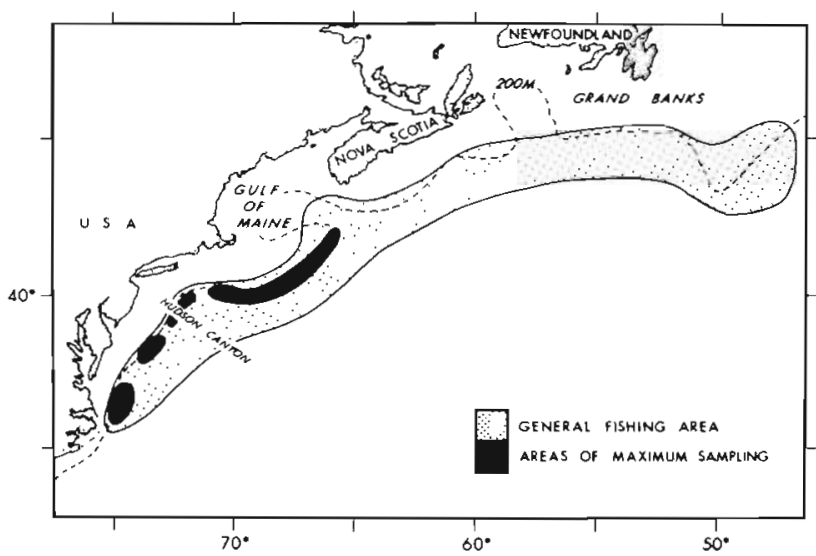

Fig. 1. Fishing area where 168 swordfish were sampled for food-habit studies. Stomachs were collected during longline fishing operations conducted from research and commercial vessels (1975-81) and at a swordfishing tournament held at Ocean City, N. J., USA (1979-80) 
(research cruises) or when brought to the dock (sport catches). Stomachs collected by commercial fishermen were iced or frozen and examined upon arrival at the laboratory.

Examination of stomach contents included identification, enumeration, and volumetric measurement of each food itern or type. A conversion of $1 \mathrm{ml}=1 \mathrm{~g}$ was used to convert volume to weight. Prey items were identified to species or to the lowest taxonomic level whenever possible. Fish and squid remains in advanced stages of digestion were classed as unidentified teleosts or Cephalopoda, respectively. Measure- ments of the maximum stomach capacity were made for a wide range of swordfish sizes. The technique, described in Stillwell \& Kohler (1982) provides a useful measure of the theoretical maximum capacity of a stomach and was used in this study to describe the degree of stomach fullness when the volume of the stomach contents is expressed as a proportion of stomach capacity.

The major forage categories were evaluated by number, volume and occurrence and compared by area, sex and size. Statistical analyses consisted of tsts of differences between means $(P<0.05)$.

Table 1. List of prey species or family groups occurring in 168 swordfish stomachs from the western North Atlantic Ocean (1975-81) by number, volume, and frequency of occurrence

\begin{tabular}{|c|c|c|c|c|c|c|}
\hline & $\begin{array}{c}\text { Num- } \\
\text { ber }\end{array}$ & $\begin{array}{l}\% \\
\text { No }\end{array}$ & $\begin{array}{l}\text { Vol } \\
\text { (mI) }\end{array}$ & $\begin{array}{c}\% \\
\text { Vol }\end{array}$ & $\begin{array}{l}\text { Fre- } \\
\text { quency }\end{array}$ & $\begin{array}{c}\% \\
\text { Frequency }\end{array}$ \\
\hline \multicolumn{7}{|l|}{ Cephalopoda } \\
\hline Ommastrephidae & 626 & 27.95 & 24,422 & 20.70 & 52 & 28.57 \\
\hline Illex illecebrosus (short-finned squid) & 665 & 29.69 & 30,036 & 25.46 & 48 & 26.37 \\
\hline Gonatidae & 13 & 0.58 & 12 & 0.01 & 5 & 2.75 \\
\hline Octopoteuthidae & 19 & 0.85 & 301 & 0.26 & 4 & 2.20 \\
\hline Histioteuthidae & 3 & 0.13 & 7 & 0.01 & 3 & 1.65 \\
\hline Onychoteuthidae & 30 & 1.34 & 163 & 0.14 & 2 & 1.10 \\
\hline Sepiolidae & 9 & 0.40 & 2 & 0.00 & 2 & 1.10 \\
\hline Octopoda & 3 & 0.13 & 2 & 0.00 & 2 & 1.10 \\
\hline Loligo pealei (long-finned squid) & 3 & 0.13 & 60 & 0.05 & 1 & 0.55 \\
\hline Thysanoteuthidae & 4 & 0.18 & 1 & 0.00 & 1 & 0.55 \\
\hline Chiroteuthidae & 2 & 0.09 & 1 & 0.00 & 1 & 0.55 \\
\hline Architeuthidae & 1 & 0.04 & 1 & 0.00 & 1 & 0.55 \\
\hline Unidentified Cephalopoda & 467 & 20.85 & 24,423 & 20.70 & 56 & 30.77 \\
\hline \multicolumn{7}{|l|}{ Teleosts } \\
\hline Merluccius bilinearis (silver hake) & 72 & 3.21 & 11,126 & 9.43 & 11 & 6.04 \\
\hline Scomber scombrus (Atlantic mackerel) & 25 & 1.12 & 6,385 & 5.41 & 9 & 4.94 \\
\hline Gadidae (codfishes) & 16 & 0.71 & 3,090 & 2.62 & 6 & 3.30 \\
\hline Pomatomus saltatrix (bluefish) & 10 & 0.45 & 4,735 & 4.01 & 5 & 2.75 \\
\hline Ammodytes americanus (sand lance) & 18 & 0.80 & 195 & 0.16 & 5 & 2.75 \\
\hline Peprilus triacanthus (butterfish) & 55 & 2.46 & 1,800 & 1.53 & 3 & 1.65 \\
\hline Cubiceps athenae (bigeye cigarfish) & 6 & 0.27 & 750 & 0.64 & 3 & 1.65 \\
\hline Gempylidae (snake mackerels) & 10 & 0.45 & 234 & 0.20 & 3 & 1.65 \\
\hline Stromateidae (butterfishes) & 5 & 0.22 & 65 & 0.06 & 3 & 1.65 \\
\hline Myctophidae (lanternfishes) & 4 & 0.18 & 18 & 0.02 & 3 & 1.65 \\
\hline Alepisauridae (lancetfishes) & 2 & 0.09 & 615 & 0.52 & 2 & 1.10 \\
\hline Brevoortia tyrannus (Atlantic menhaden) & 2 & 0.09 & 574 & 0.49 & 2 & 1.10 \\
\hline Paralepis atlantica (duckbill barracudina) & 4 & 0.18 & 310 & 0.26 & 2 & 1.10 \\
\hline Scopelosauridae & 4 & 0.18 & 51 & 0.04 & 2 & 1.10 \\
\hline Nemichthys scolopaceus (snipe eel) & 4 & 0.18 & 20 & 0.02 & 2 & 1.10 \\
\hline Sebastes maninus (redfish) & 8 & 0.36 & 2,775 & 2.35 & 1 & 0.55 \\
\hline Scorpaenidae (scorpionfishes) & 1 & 0.04 & 400 & 0.34 & 1 & 0.55 \\
\hline Clupea harengus (Atlantic herring) & 1 & 0.04 & 200 & 0.17 & 1 & 0.55 \\
\hline Hyperoglyphe perciformis (barrelfish) & 1 & 0.04 & 95 & 0.08 & 1 & 0.55 \\
\hline Cottidae (sculpins) & 1 & 0.04 & 15 & 0.01 & 1 & 0.55 \\
\hline Unidentified teleosts & 123 & 5.49 & 4,914 & 4.16 & 41 & 22.53 \\
\hline \multicolumn{7}{|l|}{ Miscellaneous } \\
\hline Animal remains & 2 & 0.09 & 190 & 0.16 & 2 & 1.10 \\
\hline Salpidae & 4 & 0.18 & 1 & 0.00 & 1 & 0.55 \\
\hline Nematoda & 17 & 0.76 & 1 & 0.00 & 1 & 0.55 \\
\hline Total & 2,240 & & 117,990 & & & \\
\hline
\end{tabular}




\section{RESULTS}

\section{Food analysis}

Stomachs from 168 swordfish of which $151(90 \%)$ contained food were examined. The total sample was comprised of 59 females, 44 males and 65 sex unknown.

The families and species of prey represented in all the stomach samples are presented in Table 1 and listed by decreasing frequency of occurrence in 2 food categories: Cephalopoda and teleosts. The table shows there is considerable diversity in the swordfish diet including near surface, demersal, and mesopelagic species.

The prey list from Table 1 is combined into 9 major forage categories (Fig. 2) in order to illustrate the importance of each in the swordfish diet.

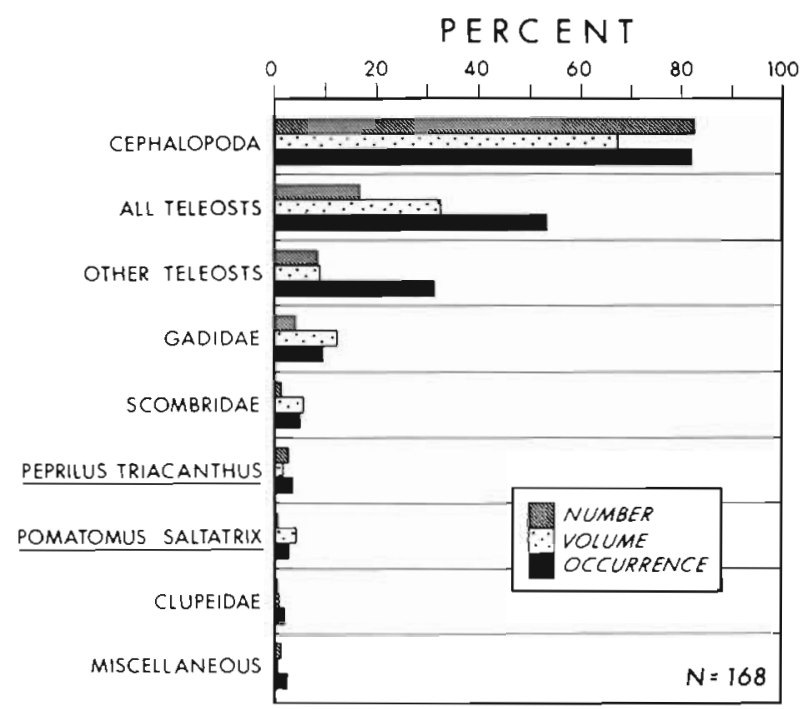

Fig. 2. Xiphias gladius. Nine major forage categories observed in 168 stomachs collected from fish caught over the slope and edge of the continental shelf in the area from Cape Hatteras, N.C. (USA) to the Tail of the Grand Banks (1975-81). Data expressed in terms of percentages by number, volume, and frequency of occurrence

\section{Cephalopoda}

Cephalopods comprised the most important food in the swordfish diet, having the highest percentages by number $(82 \%)$, volume $(67 \%)$, and frequency of occurrence (82\%) (Fig. 2). This food group was represented by 11 taxa ( 9 families, 2 species) of squids and 1 octopod (Table 1). When key characteristics necessary for identification to species were digested away, the upper and lower beaks (after Clarke 1962) and the mantle locking cartilage were the primary means of identification to family. The family Ommastrephidae occurred most frequently with Illex illecebrosus the predominant identifiable species. Members of the families Gonatidae, Octopoteuthidae, Histioteuthidae, and Onychoteuthidae occurred with decreasing frequency and were most often identified from beaks and mantle locking cartilages. Sepiolidae, Octopoda, Architeuthidae, Chiroteuthidae and Thysanoteuthidae were identified exclusively from beaks. Loligo pealei was observed in only 1 stomach from a swordfish caught at the shelf break northeast of Cape Hatteras, N. C.

Unidentified cephalopod remains accounted for a large portion of the squid component in the overall diet (Table 1). A good part of these samples were collected in the early stages of the study when no attempt was made to identify squids beyond the class level. Because the ommastrephid squids contributed significantly to the swordfish's diet, it is probable that much of the unidentified cephalopod remains were from this family group.

\section{Teleosts}

Teleosts occurred in $53 \%$ of the stomachs (Fig. 2) and were represented by 20 species or family groups (Table 1). Fish are of secondary importance in this study as seen in Fig. 2 and consist of 'Other teleosts' (a catch-all group composed of mesopelagic and miscellaneous species represented by a few individuals) followed by gadids, scombrids, butterfish, bluefish and clupeids (by percent frequency of occurrence). The first 4 fish taxa in Table 1 are the most important by volume and occurrence. The sand lance ranked fifth in occurrence but only contributed $195 \mathrm{ml}$ of food. Because of this low volume and their small size, the sand lance is probably of less significance in the diet than their frequency of occurrence implies. Silver hake was the most important fish prey by number, volume, and frequency of occurrence. One stomach contained 43 specimens averaging $28 \mathrm{~cm}$ in length. Other stomachs with silver hake held remains of 1 or 2 fish. Atlantic mackerel ranked second in importance in the diet. The possibility of confusing natural mackerel prey and bait was minimized by examining remains for hook damage. We were able to identify mackerel baits in stomachs for up to $12 \mathrm{~h}$ after ingestion. Remains in advanced stages of digestion (head, tail and abdominal cavity disintegrated) were considered to be natural prey.

The Gadidae included hakes Urophycis sp. and fish remains identified as cod or haddock. Although this family group is ranked third in Table 1 by occurrence, it actually contributed less in volume than bluefish which were larger in size than the hakes that com- 
prised most of the gadid species. Bluefish are ranked fourth based on number and occurrence but were third volumetrically (Table 1). Their occurrence, however, was restricted to stomachs collected from swordfish caught off North Carolina in spring. Gadids on the other hand, and hakes in particular, were observed in stomachs from a much larger geographic area making them a more important prey.

The remaining 15 species or families decreased rapidly in number, volume, and occurrence except for the butterfish and redfish which were important volumetrically (Table 1). All of these taxa can probably be considered occasional prey, eaten incidently as individual items or in quantity depending on their abundance or availability in a given locality. The dense schooling behavior demonstrated by butterfish and the aggregating behavior of some of the vertically migrating prey, including Nemichthyes scolopaceus, Paralepis atlantica, Myctophidae, Gempylidae, Alepisauridae, and Scopelosauridae, enhance their attraction as prey.

\section{Feeding ecology}

Feeding variability by area, sex and size

Examination of the data for areal differences in diet showed that squid was the predominant food by number, volume and occurrence south of Hudson Canyon but was about equal in importance to fish north of this area. Shifts in importance of forage groups is influenced by their availability and abundance in an area, i.e. gadids, mackerel and butterfish are more abundant to the north, whereas bluefish do not appear to be available off the continental shelf in the north, but occur in the offings of Cape Hatteras, N.C. in the spring (Wilk 1977). Silver hake occurred only in stomachs from swordfish caught between southern New England and Emerald Bank south of Nova Scotia. Mackerel occurred in stomachs throughout the study area but were most prevalent in those from north of Hudson Canyon.

We saw no indication of food preference with respect to sex or size throughout the sampling area. A scatter diagram (26 points) of swordfish fork lengths versus mantle lengths of ommastrephid squids suggested small, medium and large $(>200 \mathrm{~cm})$ fish usually fed on approximately the same size-range of squids $(7$ to $25 \mathrm{~cm}$ ). A similar trend was noted where all sizes of swordfish fed on various sized schooling and vertically migrating species, including sand lance, butterfish, lanternfish, snake mackerel, and barracudinas.

- E. B. Irby, Florida Department of Natural Resources, 727 Belvedere Road, West Palm Beach, Florida, 33405, USA
Relation of body size to food volume and maximum stomach capacity

The average round weight of 122 weighed fish was $58 \mathrm{~kg}$ (range 5.0 to $204.0 \mathrm{~kg}$ ). Females were heavier than males throughout the sampling area. Average weights for 56 females and 41 males were 57.3 and $53.0 \mathrm{~kg}$ with weight ranges of 6.0 to 204.0 and 5.0 to $131.0 \mathrm{~kg}$, respectively. There was a trend of increasing body weight from south to north with average weights of 52.0 and $45.0 \mathrm{~kg}$ for females and males south of Hudson Canyon increasing to 61.0 and $55.4 \mathrm{~kg}$ in the area north of the canyon.

The average food volume for all fish examined was $604 \mathrm{ml}$ (range 0 to $6,380 \mathrm{ml}$ ) equivalent to $1.0 \%$ of the average body weight (BW). Percentages ranked as high as $8.3 \%$ BW. Average food volumes from stomachs collected north and south of Hudson Canyon were $849 \mathrm{ml}(1.4 \% \mathrm{BW}$; avg. BW $60.3 \mathrm{~kg} ; \mathrm{n}=93)$ and $301 \mathrm{ml}(0.6 \% \mathrm{BW}$; avg. BW $52.0 \mathrm{~kg} ; \mathrm{n}=75)$, respectively. These average volumes were significantly different ( $t$-test, $\mathrm{p}<0.01$ ). To discern differences in average food volumes by size, fish were separated into juveniles and adults based on the findings of Irby (pers. comm.) who estimated weights at maturity to be 21 and $67 \mathrm{~kg}$ for males and females, respectively. Our analysis showed there was no significant difference in average food volume by weight class (immature, mature) between the sexes within each area. Food volumes increased with increasing body length, but decreased per unit body weight $\left(\mathrm{ml} \mathrm{kg}^{-1}\right)$ as fish weight increased.

To determine degree of stomach fullness, a ratio (in terms of volume) of the food content to the maximum water capacity of the stomach was calculated. The average of 92 ratios was $23.5 \%$ with a range of 0.05 to $72.4 \%$. The stomach with the highest ratio $(72.4 \%)$ was from a $304 \mathrm{~kg}$ fish that contained 9.0 l (approximately $9.0 \mathrm{~kg}$ ) of flesh from the mantle of a large squid. The mean fluid capacity of 98 stomachs was 2.3 I and amounted to $4.0 \%$ of the average body weight. The highest percentage determined was $11.2 \%$. This was from a $30 \mathrm{~kg}$ fish whose stomach held $3,350 \mathrm{ml}$ of water.

\section{Role of the sword in feeding}

Indications from this study show that the swordfish's bill is an important adaptation for obtaining food. Examinations of stomach contents revealed that swordfish engulfed whole food items as well as slashed and maimed a variety of prey types before ingesting them. Approximately 25 to $30 \%$ of the squid with mantle lengths of 7 to $25 \mathrm{~cm}$ found in the stomachs were decapitated or showed slash marks across the 
Estimates of minimum and maximum prey biomass consumed by swordfish were determined for the region of Georges Bank where the biomass of swordfish is estimated to vary from a minimum of $1091.2 \mathrm{mt}$ (metric tons) to possibly 3 times that amount (Casey et al. in press). Using the average stomach content weight of $.849 \mathrm{~kg}$ from swordfish north of Hudson Canyon which is representative of those fish from Georges Bank and $\mathrm{R}$ values from the blue $\left(0.0376 \mathrm{~h}^{-1}\right)$ and mako $\left(0.0639 \mathrm{~h}^{-1}\right)$ sharks, we calculated daily rations ranging from 0.766 to $1.302 \mathrm{~kg}$. These are equal to 1.27 and $2.15 \%$ of the average body weight for the area. In terms of prey biomass consumed, these percentages are equivalent to 13.8 and $23.5 \mathrm{mt} \mathrm{d}^{-1}$. Assuming an average swordfish residency time of $153 \mathrm{~d}$ (Casey et al. in press), the amount of prey consumed may vary from 2,100 to $3,600 \mathrm{mt}$. If the swordfish biomass is indeed 3 times greater than the minimum value suggested, the food consumed could be as high as 6,000 to $11,000 \mathrm{mt}$.

\section{DISCUSSION}

Results from this study indicate that cephalopods (squids) are the primary dietary component of the swordfish in the western North Atlantic Ocean. Yabe et al. (1959), Ovchinnikov (1970), and Toll \& Hess (1981) also showed this to be the case after examining swordfish from the Pacific, tropical Atlantic and south Florida coast, respectively. Earlier reports (Goode 1883, Rich 1947, Bigelow \& Schroeder 1953, Tibbo et al. 1961, Beckett 1974) for the western North Atlantic emphasized the importance of fish in the swordfish diet with squid being relatively unimportant. These reports were based on qualitative observations only, but results of volumetric measurements by Scott \& Tibbo (1968) of the food from 135 swordfish stomachs examined in 1964-65 from fish collected on the eastern part of Georges Bank also reflected low (16\% by volume) utilization of squid as food. Our data show that a different situation exists at the present time, which is a result of a steadily increasing abundance of squid along the continental margin from Cape Hatteras to the Gulf of Maine (Lange \& Sissenwine 1980, Lange 1982). Lange (1982) has shown that from 1968 to 1981 the estimated biomass of Illex sp. in this area increased from 1,845 to $68,611 \mathrm{mt}$. The biomass of Loligo pealei fluctuated yearly during this period from as low as 18,800 to over $51,000 \mathrm{mt}$, but since this species only occurs out to $200 \mathrm{~m}$ depth on the upper continental shelf (Lange \& Sissenwine 1980) it is not available to swordfish captured by pelagic longlines further offshore.

The importance of silver hake in the swordfish diet was noted by us (Table 1) and was also reported as a major forage item by Bigelow \& Schroeder (1953), Tibbo et al. (1961), and Scott \& Tibbo $(1968,1974)$. The last authors were the first to provide a numerical ranking of importance and showed that predation on this species occurred on Georges Bank and to the east. Woodhead (1964) reported that the silver hake is primarily a benthic species that rises off the bottom at night where according to Scott \& Tibbo (1968) it becomes available as prey for swordfish.

The occurrence of hake (Urophycis sp.) and cod-like remains (see Gadidae, Table 1) in 6 stomachs was not unexpected in view of the diversity of species observed. Scott \& Tibbo (1968) however considered hake a rare food item since they saw only 3 specimens in 1 stomach out of over 500 examined. In contrast, they reported the barracudina Paralepis atlantica to be the second most important prey by volume and occurrence in their examination of over 650 stomachs. We identified only 4 specimens in 2 stomachs, but cannot discount the possibility that a portion of the unidentified fish remains occurring in some of the stomachs was comprised of this species, making it more important than our data indicate.

The occurrence of 8 redfish in 1 stomach (Table 1) was similar to situations described by Tibbo et al. (1961) and Scott \& Tibbo (1968) where multiple numbers of a particular prey species (e.g. redfish, herring) were eaten by a single swordfish. This condition was also observed on a few occasions by commercial longliner Captains Phillip and James Ruhle (pers. comm.) while cleaning swordfish caught on the banks south of Nova Scotia and Newfoundland.

The differences observed in body weight and food volume north and south of the Hudson Canyon region cannot be discounted as artifacts in the data nor the results of too few samples. The increase in size (length and weight) of swordfish along the east coast of the US and southern Canada from south to north has been observed and reported by Beckett \& Tibbo (1968) and Beckett \& Freeman (1974). Most recently, Hoey \& Casey (pers. comm.) confirmed earlier observations that average size increases with increasing latitude after analysing dressed weight data from several thousand swordfish. The region separating our 2 areas approximates those used by Beckett \& Freeman (1974) and Hoey \& Casey (pers. comm.) to divide their data into bio-geographic zones. We are cognizant of the fact that our area south of Hudson Canyon is proportionately smaller than the nothern area but suggest the fish

\footnotetext{
- J. J. Hoey, National Marine Fisheries Service, SEFC Laboratory, 75 Virginia Beach Drive, Miami, Florida 33149, USA; J. G. Casey, National Marine Fisheries Service, NEFC Laboratory, South Ferry Road, Narragansett, Rhode Island 02882, USA
} 
Fig. 3. Mean depth zones occupied diurnally by Xiphias gladius occurring over deep-water and showing the overlap of the daily vertical migrations (DVM) of swordfish, mesopelagic fish, and pelagic squids. Number values following squid family names indicate approximate maximum depths attained by species within each family (adapted from Marshall 1971)

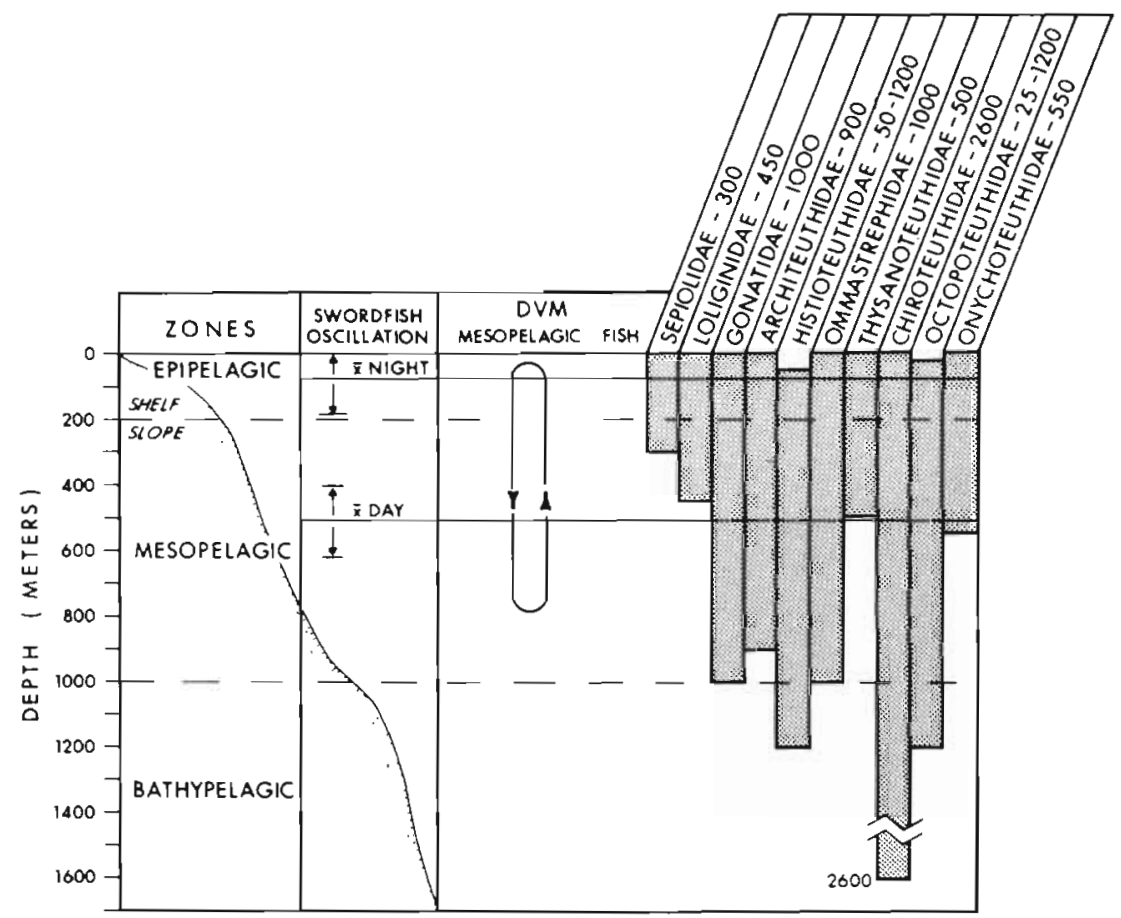

here are probably representative of those occurring at least as far south as $33^{\circ} 00^{\prime} \mathrm{N}$ latitude, which is the one used by Hoey $\&$ Casey to define the southern boundary of their 'Hatteras' zone.

The increasing food volumes in swordfish stomachs from south to north can be accounted for on the basis of increasing size of the swordfish as shown by our data. This same relation was reported for swordfish examined by Scott \& Tibbo (1968). In addition to increasing fish size, there is an increase in available prey biomass from the Middle-Atlantic Bight to Georges Bank (Clark \& Brown 1977, Cohen \& Grosslein (in press); Clark" pers. comm.). Available evidence shows that the levels of primary productivity between Cape Hatteras and the Gulf of Maine places this portion of the continental shelf among the most productive in the world, especially that area from the New York Bight to Georges Bank (O'Reilly \& Busch 1984). The increased primary productivity and prey abundance from north of Hudson Canyon to Georges Bank would thus account for the larger stomach content volumes found in this region.

The use of the sword as a physical adaptation for incapacitating or killing prey has been recognized and accepted for many years (Goode 1883, Bigelow \& Schroeder 1953, Scott \& Tibbo 1968). There appears to be no consistent pattern, however, as to when prey is slashed (Tibbo et al. 1961, Scott \& Tibbo 1968, present

\footnotetext{
- S. H. Clark, Northeast Fisheries Center, National Marine Fisheries Service, NOAA, Woods Hole, MA 02543, USA
}

study), nor does the kind of species seem to influence an onslaught since cut and whole individuals of the same species are often found in a stomach and show similar amounts of digestion. Scott \& Tibbo (1968) point out that the sword is highly specialized for lateral slashing, and to be most effective must be used on prey that are oriented vertically in the water or the swordfish must be vertically oriented itself when ascending or descending. In recent years, evidence of vertical orientation by barracudinas (Houot 1958, Rofen 1966) and some pelagic squids (Toll \& Hess 1981), including the Ommastrephidae, Thysanoteuthidae, Onychoteuthidae, and Histioteuthidae may explain why these taxa on occasion contribute significantly to the swordfish's diet.

Prey size (length) is probably not a limiting factor in food selection by the swordfish except to the extent where a prey item is too small to attract attention or so large that it cannot be cut into smaller pieces with the sword. Maksimov (1968) reported the occurrence of a $114 \mathrm{~cm}$ shark that was eaten whole by a $374 \mathrm{~cm}$ swordfish. He also reported that large Trachypteridae (kingof-the-herrings) up to $2.5 \mathrm{~m}$ in length are frequently found in swordfish stomachs. We have to assume that some of these were in pieces since it would seem an impossible feat for even a large swordfish to swallow prey of this size in one piece. Evidence from our data clearly shows that the swordfish is able to slash the thick mantle flesh of large squid into edible sized pieces.

It is generally accepted that large predatory fishes 
eat what is available in the greatest abundance in their immediate environment (Scott \& Tibbo 1968, Palko et al. 1981). The diversity of prey species occurring in swordfish stomachs (Bigelow \& Schroeder 1953, Tibbo et al. 1961, Scott \& Tibbo 1968, Beckett 1974, this study) implies an opportunistic feeding pattern which allows swordfish to forage from various trophic levels during diurnal vertical migrations (DVM). First proof of the swordfish's ability to descend deep into the mesopelagic zone was provided by Zarudski (1967) and Church (1968) when visual observations of this species were made at 610 and $654 \mathrm{~m}$, respectively. More recently, experiments by Carey \& Robison (1981) demonstrated DVMs of swordfish ranging to $617 \mathrm{~m}$. Information from one of these experiments conducted off North Carolina was used to illustrate the extent of the DVM by swordfish and how it overlaps the DVM of the mesopelagic fish and 10 families of squid found in our stomach samples (Fig. 3). The experiment showed that the average day-night depths approximated 510 and $90 \mathrm{~m}$ respectively with oscillations around these means varying from $<5$ to about $100 \mathrm{~m}$. These depths are well within the DVMs for most mesopelagic fishes (Marshall 1971) and pelagic squids occurring off the margins of the continental shelf (Voss 1967, Roper \& Young 1975, Toll \& Hess 1981). Although food may be a prime factor initiating these daily movements, sonic tracking experiments in the Atlantic and Pacific Oceans (Carey \& Robison 1981) suggest that other variables, including oxygen, buoyancy, water depth, temperature, light intensity, and location, also affect the vertical movements of swordfish.

Consumption estimates from this study suggest swordfish require a minimum-maximum food biomass of 2,100 to $11,000 \mathrm{mt}$ during their residency time on Georges Bank. Comparative estimates of consumption for all large pelagic fish (tunas, billfish) and sharks occurring on Georges Bank have been derived for the same time interval by Casey et al. (in press). These authors calculated a predator biomass ranging from 6,000 to possibly $60,000 \mathrm{mt}$, with corresponding estimates of consumption ranging from 9,000 mt to as high as $90,000 \mathrm{mt}$. A further comparison is made with the impact of marine mammals (cetaceans) on the available prey biomass of Georges Bank. Using data from a study by Scott et al. (1983) we were able to isolate information to show that during the summer and fall (corresponding closely to our swordfish residency time), the cetacean population consumes an estimated $240,000 \mathrm{mt}$ of prey biomass. This figure may be an underestimate of at least 2 to 3 times (Scott et al. 1983). Total prey consumption (primarily finfish and squid) by the large predator species occurring in the Georges Bank region could thus approach $330,000 \mathrm{mt}$ over an approximately 6 mo period. This amounts to about
$15 \%$ of the annual biomass of finfish and squid produced in the area based on a production estimate of 52 kcal m-2 $\mathrm{yr}^{-1}$ from data collected in the early 1970's (Cohen \& Grosslein in press).

Acknowledgements. Special thanks are given to commercial longliners Captain Phillip Ruhle and James Dagley of the 'Audry Lynn' and Captain James Ruhle and Joseph Garcia of the 'Darana $\mathrm{R}^{\prime}$ for providing stomach samples, and to the tournament officials of the Ocean City Marlin and Tuna Club at Ocean City, N. J. for allowing us to examine swordfish stomachs at their dock. We are grateful to those staff members of the Apex Predator Task at the NOAA, NMFS Narragansett Laboratory who assisted during field collections and Jack Casey for encouraging this research. We are also grateful to Dr. Francis Carey for discussions of his studies on diurnal behavior of swordfish and to the Captains and crew of the Polish RV 'Wieczno' who assisted during several research cruises.

\section{LITERATURE CITED}

Beckett, J. S. (1974). Biology of swordfish, Xiphias gladius L., in the northwest Atlantic Ocean. In: Shomura, R. S., Williams, F. (ed.) Proceedings of the International Billfish Symposium, Kailua-Kona, Hawaii, 9-12 Aug. 1972. Part 2. Review and Contributed Papers, U. S. Dep. Comm., NOAA Tech. Rep. NMFS SSRF-675: 105-106

Beckett, J. S., Freeman, H. C. (1974). Mercury in swordfish and other pelagic species from the western Atlantic Ocean. In: Shomura, R. S., Williams, F. (ed.) Proceedings of the International Billfish Symposium, Kailua-Kona, Hawaii, 9-12 Aug. 1972. Review and Contributed Papers, U. S. Dep. Comm., NOAA Tech. Rep. NMFS SSRF-675: $154-159$

Beckett, J. S., Tibbo, S. N. (1968). Recent changes in size composition of Canadian Atlantic swordfish catches. In: Maclellan, J.S. (ed.) Selected papers from the 1968 annual meeting. ICNAF Redbook 1968. Part III

Bigelow, H. B., Schroeder, W. C. (1953). Fishes of the Gulf of Maine. U. S. Fish Wildl. Serv. Fish. Bull. 53: 351-357

Butler, M. J. A., Mason, J. M. (1977). Behavioral studies on impounded bluefin tuna. ICCAT Collective Volume of Scientific Papers. 7 (2): 379-382

Carey, F. G., Robison, B. H. (1981). Daily patterns in the activities of swordfish Xiphias gladius, observed by acoustic telemetry. Fish. Bull. U. S. 79: 277-292

Casey, J. G., Hoey, J. J., Grosslein, M. D. (in press). Large pelagic predators - swordfish, tunas, billfishes and large sharks. In: R. Backus (ed.) The ecology of Georges Bank. MIT Press

Church, R. E. (1968). Broadbill swordfish in deep water. Sea Front. 14: 246-249

Clark, E. (1963). The maintenance of sharks in captivity, with a report on their instrumental conditioning. In: Gilbert, P. (ed.) Sharks and survival. D. C. Heath and Company, Boston, p. 115-149

Clark, S. H., Brown, B. E. (1977). Changes in biomass of finfishes and squids from the Gulf of Maine to Cape Hatteras, 1963-74, as determined from research vessel survey data. Fish. Bull. U. S. 75: 1-21

Clarke, M. R. (1962). The identification of cephalopod beaks and the relationship between beak size and total body weight. Bull. Br. Mus. (Nat. Hist.) Zool. 8: 419-480 
Cohen, E. B., Grosslein, M. D. (in press). Production on Georges Bank compared with other shelf exosystems. In: Backus (ed.) The ecology of Georges Bank. MIT Press

de Sylva, D. P. (1962). Red-water blooms off northern Chile, April-May 1956, with reference to the ecology of the swordfish and the striped marlin. Pacif. Sci. 16: 271-279

Elliott, J. M., Persson, L. (1978). The estimation of daily rates of food consumption for fish. J. Anim. Ecol. 47: 977-991

Goode, G. B. (1883). Materials for a history of the swordfishes. Rep. U. S. Comm. Fish. (1880) 8: 287-394

Gruber, S. H. (1982). Lemon sharks: supply-side economists of the sea. Oceanus 24 (4): 56-64

Houot, G. (1958). Four years of diving to the bottom of the sea. Nat. geogr. Mag. 1133 (5): 715-731

Kohler, N. E., Stillwell, C. E. (1981). Food habits of the blue shark Prionace glauca in the northwest Atlantic. ICES, C. M. $1981 / \mathrm{H}: 61,7 \mathrm{p}$

Lange, A. M. T (1982). Status of the squid (Loligo pealei and Illex illecebrosus) populations off the northeastern U.S. A. Lab. Ref. Doc. No. 82-27, $16 p$

Lange, A. M. T., Sissenwine, M. P. (1980). Biological considerations relevant to the management of squid (Loligo pealei and Illex illecebrosus) of the northwest Atlantic. Mar. Fish. Rev. 35 (7-8): 23-38

Magnuson, J. J. (1969). Digestion and food consumption by skipjack tuna (Katsuwonus pelamis). Trans. Am. Fish. Soc. 98 (3): 379-392

Maksimov, V. P. (1968). Swordfish attack on a shark. Problems of Ichthyology 8 (1): 756

Marshall, N. B. (1971). Explorations in the life of fishes. Harvard Books in Biology, 7. Harvard University Press, Cambridge, Ma.

Medred, R. J., Stillwell, C. E., Casey, J. C. (in press). Stomach contents of young sandbar sharks, Carchartinus plambeus, in Chincoteague Bay, Virginia. Fish. Bull. U.S.

O'Reilly, J. E., Busch, D. A. (1983). Phytoplankton primary production for the northwestern Atlantic shelf. Symposium on biological productivity of continental shelves in the temperate zone of the north Atlantic (March 2-5, 1982), Kiel, Federal Republic of Germany), Rapp. P.-v. Reun. Cons. int. Explor. Mer 183: 255-268

Ovchinnikov, V V. (1970). Mech-ryba i parusnikovye (Atlanticheski okean. Ekologiya i funktsional (naya morfologiya). (Swordfishes and billfishes in the Atlantic Ocean. Ecology and functional morphology.) NauchIssled. Inst. Ryb. Kohz. Okeanogr., Kaliningrad, 106 pp. [Translated by Israel Prog. Sci. Transl., 77 pp., 1971; avail. U. S. Dep. Comm., Nat1. Tech. Inf. Serv., Springfield, VA as TT71-50011.l

Palko, B. J., Beardsley, G. L., Richards, W. J. (1981). Synopsis of the biology of the swordfish Xiphias gladius Linnaeus. NOAA Tech. Rep. NMFS Circ. 441

Rich, W. H. (1947). The swordfish and the swordfishery of New England. Proc. Portland Soc. Nat. Hist. 4: 1-102

Rofen, R. R. (1966). Family Paralepididae. In: Olsen, Y H. (ed.) Fishes of the western North Atlantic. Mem. Sears Fdn mar Res. 1 (5): 205-461
Roper, C. F. E., Young, R. E. (1975). Vertical distribution of pelagic cephalopods. Smithson. Contr. Zool. 209

Sakagawa, G. T., Bell, R. R. (1980). Swordfish, Xiphias gladius. In: Shomura, R. S. (ed.) Summary report of the billfish stock assessment workshop, Pacific resources. Honolulu Laboratory, NOAA, NMFS, SWFC, Honolulu, Hawaii, December 5-14, 1977. Tech. Mem. 5: 40-50

Scott, G. P., Kenney, R. D., Thompson, T. J., Winn, H. E (1983). Functional roles and ecological impacts of the cetacean community in the waters of the northeastern U. S. continental shelf. Int. Con. Explor Mer N: 12

Scott, W. B., Tibbo, S. N. (1968). Food and feeding habits of swordfish, Xiphias gladius, in the western North Atlantic. J. Fish. Res, Bd Can. 25: 903-919

Scott, W. B., Tibbo, S. N. (1974). Food and feeding habits of swordfish, Xiphias gladius, in the western North Atlantic. In: Shomura, R. S., Williams, R. (ed.) Proceedings of the International Billfish Symposium, Kailua-Kona, Hawaii, 9-2 Aug. 1972. Part 2. Review and Contributed Papers, U. S. Dep. Comm., NOAA Tech. Rep. NMFS SSRF-675: 138-141

Stillwell, C. E., Kohler, N. E. (1982). Food, feeding habits and estimates of daily ration of the shortfin mako (Isurus oxyrinchus) in the northwest Atlantic. Can. J. Fish. aquat. Sci. 39: $407-414$

Tibbo, S. N., Day, L. R, Doucet, W. F. (1961). The swordfish (Xiphias gladius L.), its life-history and economic importance in the northwest Atlantic. Bull. Fish. Res. Bd Can., No. 130

Tiews, K. (1978). On the disappearance of bluefin tuna in the North Sea and its ecological implications for herring and mackerel. In: Hempel, G. (ed.) North Sea fish stocks recent changes and their causes. Int. Cons. Explor. Seas 172: 301-309

Toll, R. B. Hess, S. C. (1981). Cephalopods in the diet of the swordfish, Xiphias gladius, from the Florida Straits. Fish. Bull. U. S. 79: 765-774

Voss, G. L. (1967). The biology and bathymetric distribution of deep-sea cephalopods. Stud. Trop. Oceanogr. 5: $511-535$

Wilk, S. J. (1977). Biological and fisheries data on bluesfish, Pomatomus saltatrix (Linnaeus). NOAA, NMFS, NEFC, Woods Hole Lab. Tech. Ser. Rep. No. 11:1-56

Wise, J. P., Davis, C. W. (1973). Seasonal distribution of tunas and billfishes in the Atlantic. U. S. Dep. Comm., NOAA, NMFS Tech. Rep. SSRF-662: 1-24

Woodhead, P. M. J. (1964). Effects of light upon behavior and distribution of demersal fishes of the North Atlantic. ICNAF Spec. Publ. No. 6: 267-286

Yabe, H. S., Ueyanagi, S., Kikawa, S., Watanabe, H. (1959). Study on the life history of the swordfish, Xiphias gladius Linnaeus. [In Japan. Engl. summ.] Rep. Nankai Reg. Fish. Res. Lab. 10: 107-150

Zarudski, E. F. (1967). Swordfish rams the 'Alvin'. Oceanus 13 (4): $14-18$ 